\title{
Optimization of alcoholic fermentation of dragon fruit juice using response surface methodology
}

\author{
*Huan, P.T., Hien, N.M. and Anh, N.H.T. \\ Faculty of Food Science and Technology, Nong Lam University, Ho Chi Minh City, Vietnam
}

\author{
Article history: \\ Received: 20 March 2020 \\ Received in revised form: 24 \\ April 2020 \\ Accepted: 2 May 2020 \\ Available Online: 9 May \\ 2020
}

Keywords:

Fermentation,

Dragon fruit,

Fermented juice,

Saccharomyces cerevisiae,

Response surface

methodology

DOI:

https://doi.org/10.26656/fr.2017.4(5).125

\begin{abstract}
In recent years, dragon fruit has been applied in food processing with various products. The purpose of this study aimed to valorize a fermented fruit drink from a Vietnamese local dragon fruit by alcoholic fermentation of the juice using Saccharomyces cerevisiae. Response surface methodology was applied to find the optimal condition of varied factors including total soluble solids content, inoculum size of the yeast and fermentation time. The experiments were carried out according to the central composite design with the sugar content ranged from 16 to $20^{\circ}$ Brix, the inoculum size from 1 to $3 \%$ yeast and the fermentation time from 40 to $48 \mathrm{hrs}$. A quadratic model was respectively developed to correlate the investigated variables to the remained sugar content and ethanol yield of the product. The optimized conditions for fermentation were selected as $18^{\circ}$ Brix of initial fruit juice; $2 \% \mathrm{v} / \mathrm{v}$ of added yeast inoculation rate and 44 -hours fermentation time. Under these conditions, final fermented dragon fruit juice achieved alcohol content of 3.54\% v/v with remaining sugar content of $14.6^{\circ}$ Brix and a level of 'moderately like' obtained by sensorial evaluation.
\end{abstract}

\section{Introduction}

Dragon fruit (Hylocereus spp.) is a tropical fruit widely cultivated in tropical and subtropical countries, especially in Vietnam. Beside the attractive appearance, the pulp is juicy and contains numerous small black seeds. It is also considered as a potential source of micronutrients and antioxidants (Mahattanatawee et al., 2006; Lim et al., 2007; Lim et al., 2010).

Fermented fruit juice can be used as a functional fermented food with many health benefits and becomes a popular drink being enjoyed worldwide. The vitamins, minerals and nitrogenous compounds in the fruit juice are essential to yeast growth and fermentation. In general, fermented juices of other fruits are processed in the same way as wine made from grapes. During fermentation, significant compositional changes take part as yeast metabolites sugars in the juice to convert into ethanol and carbon dioxide as a by-product. In addition to fermenting, yeast influences the character and favor of products (Marquez et al., 2012). Brewer's yeast, Saccharomyces cerevisiae, is very common in the brewery and wine industry. It was reported that Saccharomyces cerevisiae has been successfully used for alcoholic fermentation of juices collected from mango, lychee and papaya (Lee et al., 2010; Reddy and Reddy,
2011; Chen and Liu, 2016). Effects of Saccharomyces cerevisiae Lalvin EC-1118 on physicochemical and oenological properties of red dragon fruit wine has been recently reported by Jiang et al. (2020). Choo et al. (2018) also studied the optimization of fermentation of Malaysian red dragon fruit for betalains concentration.

Recently in Vietnam, there has been a tendency for research to focus on adding value to local plant derivatives (Huan and Hong, 2016; Le et al., 2017). In many studies, response surface methodology (RSM) has been widely applied to optimize the processing because it can effectively reduce the number of experimental trials (Živković et al., 2018; Rahmawati et al., 2019). The aim of this work was using RSM to optimize the alcoholic fermentation process of dragon fruit juice by Saccharomyces cerevisiae in order to valorize a Vietnamese local fruit by producing a fermented drink.

\section{Materials and methods}

2.1 Materials

\subsubsection{Chemicals}

Pectinex Ultra SP-L was obtained from Novo Nordisk Ferment (Dittingen, Switzerland). FolinCiocalteu reagent $(\geq 99.8 \%$ ), potassium metabisulfite $(\geq$ 
98.8\%) and standard gallic acid (GA) ( $\geq 99.9 \%$ ) were supplied by Merck (Darmstadt, Germany). All other chemicals were analytical grade.

Raw material: White-flesh dragon fruits (Hylocereus undatus) were collected with the similarity in terms of maturity, weight and without any defects or crushes, from farmer households at Ham Thuan Nam district, Binh Thuan province, Viet Nam. They were washed and peeled before collecting fruit flesh. The flesh was stored by direct frozen $-18^{\circ} \mathrm{C}$ before usage. The pulp was crushed directly and added water at a ratio of 1:2(w/v) to get the dragon fruit juice (Wichienchot et al., 2010). The juice was treated with pectinase (Pectinex Ultra SPL) at $40^{\circ} \mathrm{C}$ in 120 mins (Truong and Dang, 2016), then filtered through a filter cloth to remove the solid parts.

\subsubsection{Yeast}

Saccharomyces cerevisiae 135 strain was obtained from the Yeast Collection of the Department of Viticulture and Enology, UC Davis (USA).

\subsubsection{Media culture}

Hansen medium (HiMedia, Mumbai, India) was used for stock culture and inoculum preparation. One liter of the medium composed of the following components: 10 $\mathrm{g}$ peptone, $50 \mathrm{~g}$ glucose, $3 \mathrm{~g} \quad \mathrm{KH}_{2} \mathrm{PO}_{4}, 2.5 \mathrm{~g}$ $\mathrm{MgSO}_{4} \cdot 7 \mathrm{H}_{2} \mathrm{O}$. The medium was sterilized at $121^{\circ} \mathrm{C}$ for 15 mins before inoculating yeast.

\subsection{Methods}

\subsubsection{Fermentation of dragon fruit juice}

The dragon fruit juice was mixed with saccharose to achieve the investigated total soluble solids content (TSS). Potassium metabisulfite was added in the juice at a concentration of $100 \mathrm{mg} / \mathrm{L}$ to inhibit bacterial growth (Santos et al., 2013). After that, yeast was added into the juice at a density of $1.2 \times 10^{7}($ cells $/ \mathrm{mL})$. Fermentation was conducted at anaerobic conditions and room temperature of $30-32^{\circ} \mathrm{C}$. With intended short fermentation time, final fermented juice contained low alcohol content and retained sweet characteristic of fruit juice as in the range of a cider.

\subsubsection{Optimization of processing parameters for fermentation}

A central composite design (CCD) was employed for the experimental data (Table 1). Three independent process variables were initial TSS $\left({ }^{\circ}\right.$ Brix; $\left.\mathrm{X}_{1}\right)$, yeast inoculation rate $\left(\% \mathrm{v} / \mathrm{v} ; \mathrm{X}_{2}\right)$ and fermentation time (hours; $X_{3}$ ). The selected response variables were TSS of the product $\left({ }^{\circ}\right.$ Brix; $\left.\mathrm{Y}_{1}\right)$ and alcohol content $\left(\mathrm{v} / \mathrm{v} ; \mathrm{Y}_{2}\right)$. JMP version 10 was used to fit the quadratic response surface model to the experimental data.
Table 1. Variable values of the parameters

\begin{tabular}{lccc}
\hline Parameters (Factors) & \multicolumn{3}{c}{ Variable values } \\
\hline $\mathrm{X}_{1}$ : Initial TSS ( ${ }^{\circ}$ Brix) & 16 & 18 & 20 \\
$\mathrm{X}_{2}$ : Yeast inoculation rate $(\% \mathrm{v} / \mathrm{v})$ & 1 & 2 & 3 \\
$\mathrm{X}_{3}$ : Fermentation time (hours) & 40 & 44 & 48 \\
\hline
\end{tabular}

\subsection{Analytical methods}

\subsubsection{Determination of total soluble solids content}

Hand-held refractometer (Atago, Japan) with detection level range of $0-32^{\circ}$ Brix was used to determine the sugar content, expressed as total soluble solids (TSS) content or Brix level of a sample. Samples were equilibrated to room temperature before used. The refractometer was first calibrated with distilled water and a reading of $0^{\circ}$ Brix obtained.

\subsubsection{Determination of $p H$}

The $\mathrm{pH}$ of samples was measured using $\mathrm{pH}$ meter (Hanna pH211, USA). Calibration was done using the buffer solutions of $\mathrm{pH} 7$ and $\mathrm{pH} 4$ prior to measurement.

\subsubsection{Determination of vitamin C content}

Vitamin $\mathrm{C}$ was determined by using the iodine titration method (Suntornsuk et al., 2002) with slight modification. Starch indicator solution was prepared by mixing $1 \mathrm{~g}$ of starch with $200 \mathrm{~mL}$ of boiling water. The solution must immediately remove from heat and left for cool. Each $25 \mathrm{~mL}$ of fresh juice sample was transferred into a $250 \mathrm{~mL}$ Erlenmeyer flask. About $25 \mathrm{~mL}$ of $2 \mathrm{~N}$ sulfuric acid was added, mixed, diluted with water (50 $\mathrm{mL})$ and starch indicator solution $(3 \mathrm{~mL})$ was added. The solution was directly titrated with $0.001 \mathrm{~N}$ standardized iodine solution. A blank titration was performed prior to titration of each sample. One $\mathrm{mL}$ of $0.001 \mathrm{~N}$ iodine was equivalent to $88.06 \mu \mathrm{g}$ ascorbic acid.

\subsubsection{Determination of total phenolic content}

The total phenolic concentration was determined spectrophotometrically by using the Folin-Ciocalteu colorimetric method (Musa et al., 2011). Samples of 1 $\mathrm{mL}$ fresh fruit juices were diluted with $4 \mathrm{~mL}$ distilled water. Then, $0.2 \mathrm{~mL}$ an aliquot of diluted juice samples and $1 \mathrm{~mL}$ of Folin-Ciocalteau reagent were mixed into a $20-\mathrm{mL}$ calibrated flask. After $1 \mathrm{~min}, 4 \mathrm{~mL}$ of sodium carbonate $(20 \% \mathrm{v} / \mathrm{v})$ was added and the volume was made to $20 \mathrm{~mL}$ with distilled water. Finally, the mixture was allowed to stand at room temperature in darkness for $30 \mathrm{~min}$ and the absorbance of the solution at $765 \mathrm{~nm}$ was measured with a UV-VIS 2502 spectrometer (LaboMed Inc, USA). The total polyphenolic concentration was calculated from a calibration curve using gallic acid as a standard $(50-500 \mathrm{mg} / 100 \mathrm{~g})$. The result was recorded in 
terms of $\mathrm{mg}$ of $\mathrm{GA}$ equivalents per $100 \mathrm{~g}$ of sample $(\mathrm{mg}$ $\mathrm{GA} / 100 \mathrm{~g}$ ).

\subsubsection{Determination of alcohol content}

Alcoholic volatile compounds in samples were separated by distillation, and the gravity of the distillate was measured by hydrometer. The alcohol content was then converted (AOAC, 1990).

\subsubsection{Sensory evaluation}

The sensory analysis was performed with nontrained panelists. The fermented dragon fruit juice was evaluated by 50 panelists of both sexes ranging from 18 to 28 years of age. Samples of $10 \mathrm{~mL}$ were served in clear glasses with a capacity of $25 \mathrm{~mL}$. The evaluation sessions took place between 9 and 10 am at room temperature $\left(30-32^{\circ} \mathrm{C}\right)$ under white light. The samples were evaluated for taste, aroma, appearance and overall impression according to the hedonic scale of nine categories: extremely dislike $=1$; very much dislike $=2$; moderately dislike $=3$; slightly dislike $=4$; neither like nor dislike $=5$; slightly like $=6$; moderately like $=7$; very much like $=8$ and extremely like $=9$ (Ihekoronye and Ngoddy, 1985).

\subsection{Statistical analysis}

Experiments were carried out in triplicate and average values with standard errors were reported. Mean values of various parameters were computed and compared using analysis of variance (ANOVA) with the JMP software (version 10.0). Means and standard errors were calculated. The significant difference was defined at $\mathrm{p}<0.05$.

\section{Results and discussion}

\subsection{Physical and chemical properties of local dragon fruit juice}

The raw material is one of the important factors affecting the quality of fermented juice. The chemical compositions of the local dragon fruit juice were given in Table 2. Comparing these results with those obtained by Liaotrakoon (2013), it was observed that $\mathrm{pH}$, total phenolic content and soluble solids of the investigated dragon fruit juice were similar $(\mathrm{pH} 4.5,18.75 \mathrm{mg}$ GA/100 g and $11.7^{\circ}$ Brix, respectively). Similar results were also found in the production of dragon fruit juice and dragon fruit wine studied by Ma et al. (2010) and Foong et al. (2012) respectively. While the vitamin C content $(16.66 \pm 0.17 \mathrm{mg} / 100 \mathrm{~mL})$ of the juice found in this study is higher than the one reported by Liaotrakoon (2013) $(7.32 \pm 0.21 \mathrm{mg} / 100 \mathrm{~mL})$. The difference in vitamin $\mathrm{C}$ content was most likely due to differences in the determination of vitamin $\mathrm{C}$ method, maturation stage and environmental growth variation of the fruit.

Table 2. Physical and chemical properties of dragon fruit juice

\begin{tabular}{lc}
\hline Parameters & Results \\
\hline TSS $\left({ }^{\circ}\right.$ Brix $)$ & $11.8 \pm 0.2$ \\
pH & $4.5 \pm 0.03$ \\
Vitamin C $(\mathrm{mg} / 100 \mathrm{~mL})$ & $16.66 \pm 0.17$ \\
TTA $(\mathrm{g}$ citric acid $/ 100 \mathrm{~mL})$ & $0.58 \pm 0.02$ \\
Total phenolic content $(\mathrm{mg} \mathrm{GA} / 100 \mathrm{~g})$ & $17.04 \pm 0.14$ \\
\hline
\end{tabular}

3.2 Evaluation of key variables affecting fermentation of dragon fruit juice

The fermentation process was affected by different factors, especially the initial sugar content ( ${ }^{\circ}$ Brix), yeast inoculation rate $(\% \mathrm{v} / \mathrm{v})$ and fermentation time (hours). Results of remained sugar content ( $\left({ }^{\circ}\right.$ Brix) as well as the alcohol content $(\% \mathrm{v} / \mathrm{v})$ of final fermented dragon fruit juices at different treatment levels were shown in Table 3. The analysis of variance (ANOVA) was performed for each response and optimal models.

\subsubsection{Effect of processing factors on sugar content of fermented product}

The responses of remaining sugar content left behind the alcoholic fermentation of dragon fruit juice can be obtained from the response surface design method. Statistical significance of the model term coefficients was determined by student's t-test and $p$ test values as illustrated in Table 4.

It was shown that initial sugar content, yeast rate and fermentation time all significantly affected the remaining sugar content of the fermented product $(p<0.05)$. Quadratic equation showing the effect of factors on the Brix level of the final product was obtained as in Equation 1.

$$
\begin{aligned}
& \mathrm{Y}_{1}=14.51+1.56 \mathrm{X}_{1}-0.98 \mathrm{X}_{2}-0.42 \mathrm{X}_{3}- \\
& 0.325 \mathrm{X}_{1} \mathrm{X}_{3}+1.634 \mathrm{X}_{1}^{2}
\end{aligned}
$$

In which, $\mathrm{Y}_{1}$ is TSS of fermented product ( $\left.{ }^{\circ} \mathrm{Brix}\right) ; \mathrm{X}_{1}$ is initial TSS $\left({ }^{\circ} \mathrm{Brix}\right) ; \mathrm{X}_{2}$ is yeast rate $(\% \mathrm{v} / \mathrm{v}) ; \mathrm{X}_{3}$ is fermentation time (hours).

The correlation between the initial Brix level and the Brix level of final fermented dragon juice was positively correlated. It showed that the higher the Brix level before fermentation was, the more Brix level after fermentation was obtained. The yeast inoculation rate and fermentation time-correlated negatively with the Brix level of product. Because more yeasts would utilize more sugar to grow and produce alcohol, the longer fermentation time lasted, the more sugar was consumed by yeast for fermentation, which led to a reduction of Brix level in the fermented product. The amount of yeast added to fermentation affected on criteria of final products as high or low Brix level. In another study, 
Table 3. Changes in total soluble solids content (TSS) and alcohol content of product at different treatment levels

\begin{tabular}{ccccccc}
\hline Exp. & Code & $\begin{array}{c}\text { Initial TSS, } X_{1} \\
\left({ }^{\circ} \text { Brix }\right)\end{array}$ & $\begin{array}{c}\text { Yeast rate, } X_{2} \\
(\% \mathrm{v} / \mathrm{v})\end{array}$ & $\begin{array}{c}\text { Fermentation time, } \mathrm{X}_{3} \\
\text { (hours })\end{array}$ & $\begin{array}{c}\text { TSS of product, } Y_{1} \\
\left({ }^{\circ} \text { Brix }\right)\end{array}$ & $\begin{array}{c}\text { Alcohol content, } Y_{2} \\
(\% \mathrm{v} / \mathrm{v})\end{array}$ \\
\hline 1 & --- & 16 & 1 & 40 & 15.4 & 0.62 \\
2 & --+ & 16 & 1 & 48 & 15.2 & 0.75 \\
3 & $\mathrm{a} 00$ & 16 & 2 & 44 & 14.6 & 2.54 \\
4 & -+- & 16 & 3 & 40 & 14.8 & 2.27 \\
5 & -++ & 16 & 3 & 48 & 13.2 & 3.52 \\
6 & $0 \mathrm{a} 0$ & 18 & 1 & 44 & 15.9 & 2.04 \\
7 & $00 \mathrm{a}$ & 18 & 2 & 40 & 14.9 & 3.12 \\
8 & 0 & 18 & 2 & 44 & 14.6 & 3.54 \\
9 & 0 & 18 & 2 & 44 & 14.6 & 3.54 \\
10 & $00 \mathrm{~A}$ & 18 & 2 & 48 & 13.3 & 4.22 \\
11 & $0 \mathrm{~A} 0$ & 18 & 3 & 44 & 13.9 & 4.54 \\
12 & +-- & 20 & 1 & 40 & 19.2 & 1.03 \\
13 & +-+ & 20 & 1 & 48 & 19 & 1.42 \\
14 & A00 & 20 & 2 & 44 & 17.6 & 2.05 \\
15 & ++- & 20 & 3 & 40 & 16.8 & 3.76 \\
16 & +++ & 20 & 3 & 48 & 16.2 & 4.82 \\
\hline
\end{tabular}

(+) Upper limit value, (-) Lower limit value, (a) High axis value, (A) Low axis value, (0) Value at midpoint

Table 4. Effect of factors on remaining sugar content of the final fermented product

\begin{tabular}{lcccc}
\hline Term & Estimate & Std Error & $\mathrm{t}$ Ratio & Prob $>|\mathrm{t}|$ \\
\hline Intercept & 14.510345 & 0.140061 & 103.6 & $<.0001^{*}$ \\
TSS $(16,20)$ & 1.56 & 0.093554 & 16.67 & $<.0001^{*}$ \\
Yeast rate $(1,3)$ & -0.98 & 0.093554 & -10.48 & $<.0001^{*}$ \\
Time $(40,48)$ & -0.42 & 0.093554 & -4.49 & $0.0042^{*}$ \\
TSS*Yeast rate & -0.325 & 0.104596 & -3.11 & $0.0209^{*}$ \\
TSS*Time & 0.125 & 0.104596 & 1.2 & 0.2771 \\
Yeast rate*Time & -0.225 & 0.104596 & -2.15 & 0.075 \\
TSS*TSS & 1.6344828 & 0.182204 & 8.97 & $0.0001^{*}$ \\
Yeast rate*Yeast rate & 0.4344828 & 0.182204 & 2.38 & 0.0544 \\
Time*Time & -0.365517 & 0.182204 & -2.01 & 0.0917 \\
\hline
\end{tabular}

glucose consumption profile was reported during grape juice fermentation by Saccharomyces cerevisiae (Tronchoni et al., 2009).

\subsubsection{Effect of factors on alcohol content of fermented product}

Effect of processing parameters on the alcohol content of the final product can be observed through the student's t-test and $p$ test values in Table 5. In particular, only two factors including initial Brix level and yeast rate were positively correlated to the alcohol content of the fermented product. Fermentation time did not show a significant effect due to a short-investigated time in the range of 40 - $48 \mathrm{hrs}$. Hence there was not any significant difference among alcohol contents of fermented juice products.

Quadratic equation showing the effects of processing factors on alcohol content was obtained in Equation 2.
$\mathrm{Y}_{2}=3.513+0.338 \mathrm{X}_{1}+1.305 \mathrm{X}_{2}+0.214 \mathrm{X}_{1} \mathrm{X}_{2}-$ $1.204 \mathrm{X}_{1}^{2}$

In which, $\mathrm{Y}_{2}$ is alcohol content of fermented product ( $\%$ $\mathrm{v} / \mathrm{v}) ; \mathrm{X}_{1}$ is initial TSS $\left({ }^{\circ} \mathrm{Brix}\right) ; \mathrm{X}_{2}$ is yeast rate $(\% \mathrm{v} / \mathrm{v})$.

In addition, it can be also observed that two factors including the Brix level of the juice and yeast inoculation rate had an interaction during fermentation. This meant that when the initial sugar level was too low, the yeast would not have enough nutrients to increase biomass, which led to producing low alcohol content. Too much sugar added would inhibit yeast activity due to large osmotic pressure difference, resulting in the reduction of performance yeast. However, Brix level in the range of $16-20^{\circ}$ Brix was still at the permitted range of Brix level (10-25 Brix) (Ough, 1966) thus fermentation activity still occurred normally. Turhan et al. (2010) reported a significant effect of inoculum size of Saccharomyces cerevisiae on the ethanol production from carob extract. It was also reported that Saccharomyces cerevisiae can 
Table 5. Effect of factors on the alcohol content of the fermented product

\begin{tabular}{lcccc}
\hline Term & Estimate & Std Error & $\mathrm{t}$ Ratio & Prob $>|\mathrm{t}|$ \\
\hline Intercept & 3.5127586 & 0.188077 & 18.68 & $<.0001^{*}$ \\
TSS $(16,20)$ & 0.338 & 0.125626 & 2.69 & $0.0360^{*}$ \\
Yeast rate $(1,3)$ & 1.305 & 0.125626 & 10.39 & $<.0001^{*}$ \\
Time $(40,48)$ & 0.393 & 0.125626 & 3.13 & 0.2040 \\
TSS*Yeast rate & 0.21375 & 0.140454 & 1.52 & $0.0189^{*}$ \\
TSS*Time & 0.00875 & 0.140454 & 0.06 & 0.9523 \\
Yeast rate*Time & 0.22375 & 0.140454 & 1.59 & 0.1623 \\
TSS*TSS & -1.204138 & 0.244667 & -4.92 & $0.0027^{*}$ \\
Yeast rate*Yeast rate & -0.209138 & 0.244667 & -0.85 & 0.4255 \\
Time*Time & 0.1708621 & 0.244667 & 0.70 & 0.5111 \\
\hline
\end{tabular}

convert the sugar in the fruit juices into alcohol and organic acids, that later react to form aldehydes, esters, and other chemical compounds (Fleet, 2003; Duarte et al., 2010).

\subsection{Optimization of processing parameters for fermentation}

A three-dimensional response surface for the impact of the investigated processing factors on the Brix level and alcohol content of the fermented product was established (Figure 1).

Each point on the three-dimensional surface in Figure 1 illustrated a value of Brix level or alcohol content of the final product which was affected by three investigated processing factors. According to response surface, levels and trend of influence of all three investigated factors on the monitored results can be observed. As results, the lowest or highest alcohol content and Brix level of fermented product could be observed. After being analyzed by the developed model, parameters were optimized and showed in Figure 2.

Table 6 shows the value of Brix level and alcohol content of the product which was predicted at the

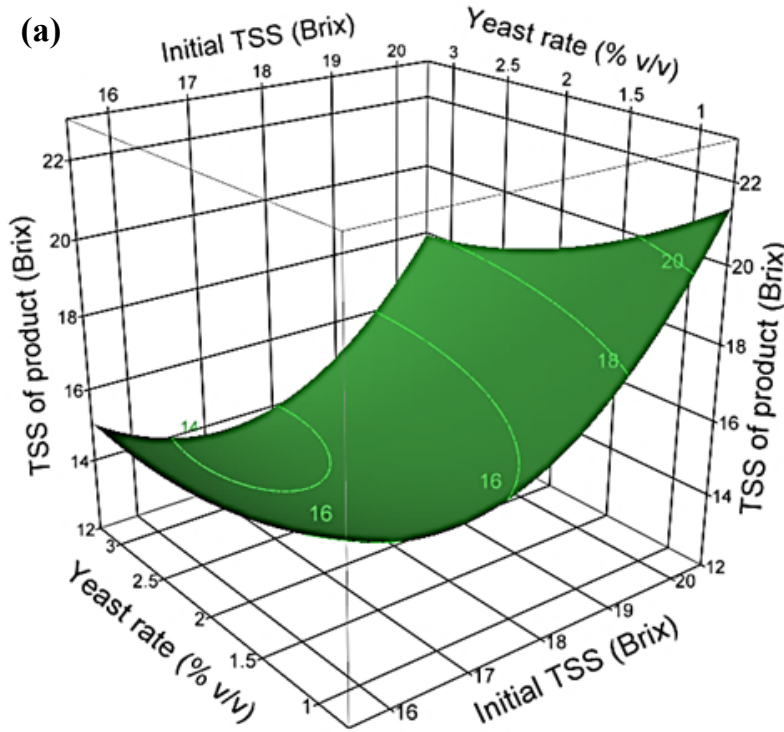

optimum conditions of process parameters in comparison with the actual value obtained by carrying out the experiment. It can be seen that at the optimum levels of processing parameters, the experimental value of Brix level of $14.6^{\circ}$ Brix and alcohol content of $3.54 \%(\mathrm{v} / \mathrm{v})$ were obtained which were very close to its predicted value by the quadratic model. Thus, the processing parameters consisting of $18^{\circ} \mathrm{Brix} ; 2 \%(\mathrm{v} / \mathrm{v})$ yeast rate and fermentation time of $44 \mathrm{hrs}$ were finally selected for the dragon fruit juice fermentation by S. cerevisiae 135 . The optimized initial sugar content obtained in this study is in the same range with those reported in alcoholic fermentation by Saccharomyces cerevisiae of guava and cashew apple juices (Attri, 2009; Sevda and Rodrigues, 2011)

Table 6. Predicted and actual values of the optimum experimental conditions

\begin{tabular}{lcc}
\hline Parameters & $\begin{array}{c}\text { Predicted } \\
\text { value }\end{array}$ & $\begin{array}{c}\text { Actual } \\
\text { value }\end{array}$ \\
\hline Initial TSS $\left({ }^{\circ}\right.$ Brix $)$ & 18 & 18 \\
Yeast rate $(\% \mathrm{v} / \mathrm{v})$ & 2 & 2 \\
Fermented time (hours) & 44 & 44 \\
TSS of product ( ${ }^{\circ}$ Brix $)$ & 14.5 & 14.6 \\
Alcohol content of product $(\% \mathrm{v} / \mathrm{v})$ & 3.51 & 3.54 \\
\hline
\end{tabular}

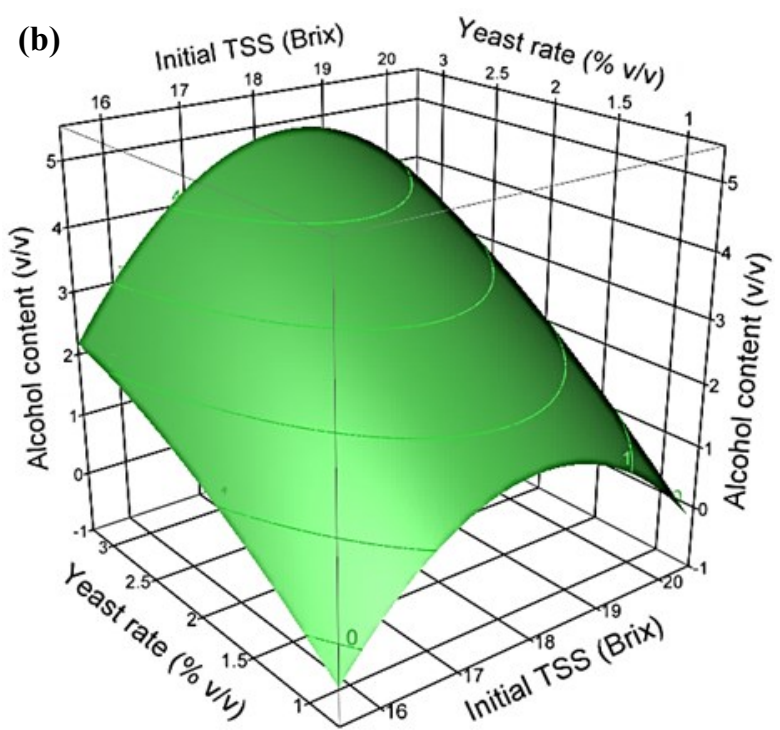

Figure 1. Response surface of Brix level (a) and alcohol content (b) of fermented product 


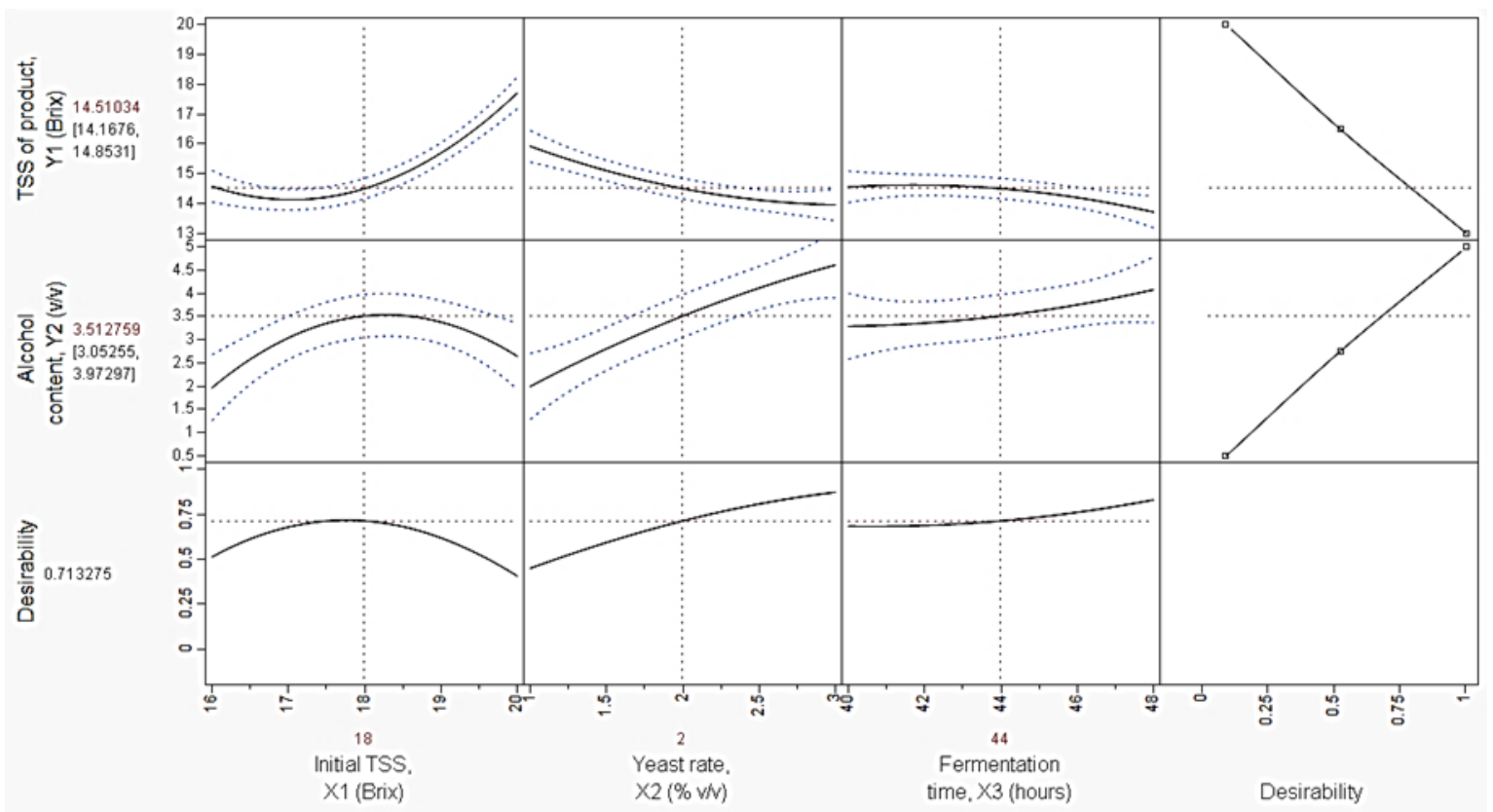

Figure 2. Prediction profile analysis of alcoholic fermentation

\subsection{Sensory evaluation of fermented dragon fruit juice}

In addition, to evaluate the quality of products, a sensory test of fermented dragon fruit juice by consumer acceptance test was performed. Table 7 presents the frequency of acceptance attributed to fermented juice by 50 untrained tasters, designated based upon a nine point hedonic scale. Similar averages were recorded for the four evaluated attributes, where the appearance achieved the highest value, followed by the general aroma, taste with scores of 7.8, 7.3 and 7.1. The appearance attribute had the highest frequency of the maximum value in the hedonic scale ( 13 votes $-26 \%$ of the tasters). The taste of the fermented juice reached an average of 7.1, indicating that the tasters 'moderately liked' the taste of the fermented dragon fruit juice. The overall attribute which corresponds to the total acceptance of the fermented juice by the tasters reached the highest frequency ( 23 tasters, $46 \%$ of the total) in point 8 on the hedonic scale, meaning that the tasters 'liked very much' the fermented juice. Therefore, fermented dragon fruit juice by Saccharomyces cerevisiae 135 was accepted by the customer, hence it can be prompted as potential products for the beverage industry as well as the beverage market.

Table 7. Frequency and average notes for the attributes of sensory analysis

\begin{tabular}{lcccccccccc}
\hline & \multicolumn{10}{c}{ Frequency and average notes } \\
\hline Attribute & 1 & 2 & 3 & 4 & 5 & 6 & 7 & 8 & 9 & Mean \\
Appearance & 1 & - & 1 & - & - & 4 & 4 & 27 & 13 & 7.8 \\
Aroma & - & - & - & 1 & 1 & 10 & 12 & 20 & 6 & 7.3 \\
Taste & - & - & - & 2 & 4 & 9 & 12 & 18 & 5 & 7.1 \\
Overall & - & - & - & 1 & - & 4 & 16 & 23 & 6 & 7.6
\end{tabular}

Extremely dislike $=1$, very much dislike $=2$, moderately dislike $=3$, slightly dislike $=4$, neither like nor dislike $=5$, slightly like $=6$, moderately like $=7$, very much like $=8$ and extremely like $=9$.

\section{Conclusion}

Fermented dragon fruit juice by Saccharomyces cerevisiae 135 with total soluble solid content of $11.8^{\circ}$ Brix, $\mathrm{pH} 4.5$, vitamin $\mathrm{C}$ concentration of $16.66 \mathrm{mg} / 100$ $\mathrm{mL}$, total acidity of $0.58 \mathrm{~g}$ of citric acid/100 $\mathrm{mL}$ and total phenolic content of $17.04 \mathrm{mg} \mathrm{GA} / 100 \mathrm{~g}$ was successfully produced. The selected yeast strain has a good impact on sugar consumption and alcohol production during the primary fermentation process. The optimized conditions for fermentation were established as $18^{\circ}$ Brix of fruit juice; $2 \%$ added yeast inoculation rate and 44-hour fermentation time. Under the optimal fermentation conditions, the final product achieved alcohol content of $3.54 \%(\mathrm{v} / \mathrm{v})$ with remaining sugar content of $3.54^{\circ}$ Brix. The sensorial quality of the fermented juice was accepted according to the results of the consumer acceptance test.

\section{Conflict of interest}

The authors declare no conflict of interest.

\section{References}

AOAC. (1990). Alcohol in wines. By volume from specific gravity. Method 920.57. Official Methods of Analysis. USA: AOAC International.

Attri, B.L. (2009). Effect of initial sugar concentration on the physico-chemical characteristics and sensory qualities of cashew apple wine. Natural Product Radiance, 8(4), 374-379.

Chen, D. and Liu, S.Q. (2016). Transformation of chemical constituents of lychee wine by simultaneous alcoholic and malolactic fermentations. Food Chemistry, 196, 988-995. https:// doi.org/10.1016/j.foodchem.2015.10.047 
Choo, K.Y., Kho, C., Ong, Y.Y., Thoo, Y.Y., Lim, L.H., Tan, C.P. and Ho, C.W. (2018). Fermentation of red dragon fruit (Hylocereus polyrhizus) for betalains concentration. International Food Research Journal, 25(6), 2539-2546.

Duarte, W.F., Dias, D.R., Oliveira, J.M., Teixeira, J.A., de Almeida e Silva, J.B. and Schwan, R.F. (2010). Characterization of different fruit wines made from cacao, cupuassu, gabiroba, jaboticaba and umbu. LWT - Food Science and Technology, 43(10), 15641572. https://doi.org/10.1016/j.lwt.2010.03.010

Fleet, G.H. (2003). Yeast interactions and wine flavour. International Journal of Food Microbiology, 86(1), 11-22. https://doi.org/10.1016/S0168-1605(03)00245 $-9$

Foong, J.H., Hon, W.M. and Ho, C.W. (2012). Bioactive compounds determination in fermented liquid dragon fruit (Hylocereus polyrhizus). Broneo Science, 31, 37 $-56$.

Huan, P.-T. and Hong, N.T.M. (2016). Polyphenol content and antioxidant capacity of herbal tea from Vietnamese water hyssop (Bacopa monnieri). International Journal on Advanced Science, Engineering and Information Technology, 6(1), 6168. https://doi.org/10.18517/ijaseit.6.1.649

Ihekoronye, A.I. and Ngoddy, P.O. (1985). Integrated food science and technology for the tropics. London: Macmillan.

Jiang, X., Lu, Y. and Liu, S.Q. (2020). Effects of different yeasts on physicochemical and oenological properties of red dragon fruit wine fermented with Saccharomyces cerevisiae, Torulaspora delbrueckii and Lachancea thermotolerans. Microorganisms, 8 (3), $315 . \quad \mathrm{https} / / /$ doi.org/10.3390/ microorganisms 8030315

Le, T.T., Phan, T.H. and Raes, K. (2017). Establishment of a processing procedure for manufacturing dried dragon fruit. Journal of Agricultural Sciences and Technology, 6, 32-38.

Lee, P.R., Ong, Y.L., Yu, B., Curran, P. and Liu, S.Q. (2010). Profile of volatile compounds during papaya juice fermentation by a mixed culture of Saccharomyces cerevisiae and Williopsis saturnus. Food Microbiology, 27(7), 853-861. https:// doi.org/10.1016/j.fm.2010.05.010

Liaotrakoon, W. (2013). Characterization of dragon fruit (Hylocereus spp.) components with valorization potential. Belgium; Ghent University, PhD Thesis.

Lim, H.K., Tan, C.P., Karim, R., Ariffin, A.A. and Bakar, J. (2010). Chemical composition and DSC thermal properties of two species of Hylocereus cacti seed oil: Hylocereus undatus and Hylocereus polyrhizus. Food Chemistry, 119(4), 1326-1331. https://doi.org/10.1016/j.foodchem.2009.09.002

Lim, Y.Y., Lim, T.T. and Tee, J.J. (2007). Antioxidant properties of several tropical fruits: A comparative study. Food Chemistry, 103(3), 1003-1008. https:// doi.org/10.1016/j.foodchem.2006.08.038

Ma, S.H., Liu, C.H. and Pu, Q.X. (2010). Study on the fermentation techniques of pitaya fruit wine. LiquorMaking Science and Technology, 6, TS261.4

Mahattanatawee, K., Manthey, J.A., Luzio, G., Talcott, S.T., Goodner, K. and Baldwin, E.A. (2006). Total antioxidant activity and fiber content of select Florida-grown tropical fruits. Journal of Agricultural and Food Chemistry, 54(19), 7355-7363. https:// doi.org/10.1021/jf060566s

Marquez, A., Serratosa, M.P., Lopez-Toledano, A. and Merida, J. (2012). Colour and phenolic compounds in sweet red wines from Merlot and Tempranillo grapes chamber-dried under controlled conditions. Food Chemistry, 130(1), 111-120. https:// doi.org/10.1016/j.foodchem.2011.07.010

Musa, K.H., Abdullah, A., Jusoh, K. and Subramaniam, V. (2011). Antioxidant activity of pink-flesh guava (Psidium guajava L.): effect of extraction techniques and solvents. Food Analytical Methods, 4(1), 100107. https://doi.org/10.1007/s12161-010-9139-3

Ough, C.S. (1966). Fermentation rates of grape juice. II effect of initial ${ }^{\circ}$ Brix, $\mathrm{pH}$, and fermentation temperature. American Journal of Enology and Viticulture, 17(1), 20-26.

Rahmawati, R., Hunaefi, D., Saputra, D., Apriliani, A. and Jenie, B. (2019). Optimization of temperature and drying time of indigenous cocktail yeast mold culture using response surface methodology (RSM). Food Research, 4(2), 389-395. https:// doi.org/10.26656/fr.2017.4(2).247

Reddy, L.V.A. and Reddy, O.V.S. (2011). Effect of fermentation conditions on yeast growth and volatile composition of wine produced from mango (Mangifera indica L.) fruit juice. Food and Bioproducts Processing, 89(4), 487-491. https:// doi.org/10.1016/j.fbp.2010.11.007

Santos, C.C.A.D.A., Duarte, W.F., Carreiro, S.C. and Schwan, R.F. (2013). Inoculated fermentation of orange juice (Citrus sinensis L.) for production of a citric fruit spirit. Journal of the Institute of Brewing, 119(4), 280-287. https://doi.org/10.1002/jib.89

Sevda, S. and Rodrigues, L. (2011). Fermentative behavior of Saccharomyces strains during guava (Psidium Guajava L.) must fermentation and optimization of guava wine product. Journal of food processing and Technology, 118, 1-9. 
Suntornsuk, L., Gritsanapun, W., Nilkamhank, S. and Paochom, A. (2002). Quantitation of vitamin C content in herbal juice using direct titration. Journal of Pharmaceutical and Biomedical Analysis, 28(5), 849-855. https://doi.org/10.1016/S0731-7085(01) 00661-6

Tronchoni, J., Gamero, A., Arroyo-López, F.N., Barrio, E. and Querol, A. (2009). Differences in the glucose and fructose consumption profiles in diverse Saccharomyces wine species and their hybrids during grape juice fermentation. International Journal of Food Microbiology, 134(3), 237-243. https://doi.org/10.1016/j.ijfoodmicro.2009.07.004

Truong, N.M. and Dang, Q.T. (2016). Application of hydrolytic enzymes for improvement of red dragon fruit juice processing. Asia Pacific Journal of Sustainable Agriculture, Food and Energy, 4(1), 1-4.

Turhan, I., Bialka, K.L., Demirci, A. and Karhan, M. (2010). Ethanol production from carob extract by using Saccharomyces cerevisiae. Bioresource Technology, 101(14), 5290-5296. https:// doi.org/10.1016/j.biortech.2010.01.146

Wichienchot, S., Jatupornpipat, M. and Rastall, R.A. (2010). Oligosaccharides of pitaya (dragon fruit) flesh and their prebiotic properties. Food Chemistry, 120(3), 850-857. https://doi.org/10.1016/ j.foodchem.2009.11.026

Živković, J., Šavikin, K., Janković, T., Ćujić, N. and Menković, N. (2018). Optimization of ultrasoundassisted extraction of polyphenolic compounds from pomegranate peel using response surface methodology. Separation and Purification Technology, 194, 40-47. https://doi.org/10.1016/ j.seppur.2017.11.032 